\title{
EMPIRICAL ANALYSIS \\ OF SLOVENIAN HOTEL INDUSTRY PERFORMANCE WITH THE RELATIVE RESIDUAL INCOME APPROACH
}

\author{
Igor Stubelj ${ }^{1}$ \\ Mateja Jerman ${ }^{2}$
}

DOI: https://doi.org/10.31410/tmt.2019.397

\begin{abstract}
This paper's focus is on the relative residual income approach as a firm's performance measure. The aim is to analyse the financial performance of the Slovenian hotel industry for a period from the year 2009 to 2018, with a relative residual income measure that takes into account the required return on equity capital. Taking into account the required return on equity is essential in firm's performance valuation as is the opportunity cost for investors. To add value, a firm's return on equity must exceed the required return on equity. Our results show that relative residual income of Slovenian hotel industry is negative for the entire analysed period. The same resulted for groups of large, medium-sized, and small firms. The situation is improving but is still not at the desired level that is adding value of equity capital for owners. Our further analysis shows that the Slovenian hotel industry is riskier than all Slovenian firms (i.e. average risky firm) in the observed period. However, the return on equity is much lower than of all Slovenian firms in the observed period. This gives additional support to our findings.
\end{abstract}

Keywords: relative residual income, hotel industry, tourism, required return on equity capital, performance measure.

\section{INTRODUCTION}

$\mathrm{I}^{\mathrm{n}}$ n the last decade we were facing a significant growth of tourism demand. Official statistics often shows only the direct effects of tourism in the economy, while the World Travel \& Tourism Council (WTTC) emphasizes that the effects of tourism are much wider. The WTTC defines the effects of tourism as direct, indirect and induced (consumption of tourism workers who are directly or indirectly employed by the tourism industry). Globally, in 2018, the average growth of tourism industry in GDP was 3.9\%, exceeding the global average growth of GDP, which reached 3.2\%. The direct and indirect effects of tourism were estimated at $10.4 \%$ of global GDP, $4.4 \%$ of total investment and $6.5 \%$ of total exports. The expectations about the industry's future growth are also favourable (World Travel \& Tourism Council, 2019b).

The largest tourism destination for international arrivals in the world is the Europe (World Travel \& Tourism Council, 2019a). The WTTC estimates the direct effects of tourism in Europe in 2017 at $3.6 \%$, while the overall impact is assessed to be $9.9 \%$ (World Travel \& Tourism Council, 2018). Growth of the volume and value of tourism in Europe differs among countries. In 2018, the strongest growth was evidenced in Southern/Mediterranean Europe (World Travel \& Tourism Council, 2019a).

For Slovenia, which is located in the Southern/Mediterranean Europe, the tourism industry is an important branch due to the following reasons. Recent data for Slovenia shows that in 2018 the total impact of tourism industry on Slovene GDP amounted to 12.3\%. 2018 was the fifth con-

\footnotetext{
1 University of Primorska, Faculty of Management, Cankarjeva 5, 6000 Koper, Slovenia

2 University of Primorska, Faculty of Management, Cankarjeva 5, 6000 Koper, Slovenia
} 
secutive record year for the Slovene tourism industry. The number of tourist arrivals amounted almost to 6 million and, overnight stays to 15.7 million. Data from 2018 show that the industry employs approximately 57,800 persons, which represents $6.5 \%$ of all employees (STO, 2019).

The most important tourism industry within the Slovene tourism sector, represent hotels and similar establishments, both in terms of total revenues and number of employees (AJPES, 2019). Within the Standard Classification of Activities (SCA), hotels and similar accommodation (I55.100) are classified within Activities of catering. In the period 2007-2017, the total number of all overnight stays in Slovenia increased by $52.4 \%$ and in hotels and similar accommodation facilities by $39.8 \%$. In 2017, the share of overnight stays in hotels and similar establishments in relation to total lodging facilities amounted to $62.2 \%$, the share of revenue was $86.5 \%$, and the share of employees reached 93.2\% (Vesenjak, 2018).

Despite the fact that statistical data show a good performance of the industry, this is not the case when we consider hotels' financial results. In the period 2007-2017 hotel revenues grew up in nominal terms by $31.9 \%$ (real growth of $13.7 \%$ ), while at the same time total room revenue was up by only $1.1 \%$ (real growth of $-12.8 \%$ ) (Vesenjak, 2018). Stubelj et al. (2011) found that the Slovenian hotel industry did not generate value for their owners. Their analysis was performed on data from the period 2005-2008. The principal reason for these results were excessive costs of operations, that lead to low or even negative return on equity.

In accordance with the presented statistics, it is obvious that the tourism industry represents an important branch in the case of the Slovenian economy. This is an argument in favour of performing an empirical analysis on the relative residual income of Slovenian hotel firms. Since statistical data show a good performance of the industry, while on the other hand financial data indicate that the industry is not performing well, our research question is: Does Slovenian hotel industry has positive relative residual income and creates value for their owners?

Our empirical analysis was performed on data of large, medium-sized and small hotels and similar establishments (those who operate in STA I55.100) for the period 2009-2018. Data was collected from GVIN financial database, from hotel industry firms' balance sheets and income statements. We gathered also other data from different databases for the purpose of the required return on equity capital estimation.

The paper is organized as follows. After the introduction the theoretical background of the research is presented, where the methodology of relative residual income and required return on equity capital is explained. The description of data used is presented in the fifth part. The obtained results of the analysis and the discussion constitute the seventh part. The eight part concludes the paper.

\section{RESIDUAL INCOME APPROACH AS AN INVESTMENT DECISION-MAKING MEASURE}

Investing in a firm is risky. Investors can reduce the risk diversifying their investment in different assets, but they cannot eliminate all the risk. To be compensated for the risk they require a proper return. If we assume that investors are risk averse, they seek the highest possible return for the maximum risk they can accept. Equity capital is a rare commodity; it is a production factor and is not for free. In order to get the necessary equity, capital firms must demonstrate the ability to compensate investors for risk. Earning the required return is a mandate for all capital firms. 
For efficiency analysis of invested capital in firms, investors can use measures such as return on equity, return on assets, return on invested capital, and others. These measures, however, miss one crucial factor, that is the required return of equity capital. ${ }^{3}$ A positive return on equity is not enough to satisfy investors; investors expect to be rewarded according to the risk of the investment. Only if an equity investment's return is higher than the required return that accounts for risk, the investment adds value to invested equity in a firm.

Investors and managers must be interested in the value of their business. Financial management theory is based on the premise that the managers' primary objective should be to increase the value of investors' (i.e. owners') equity capital. ${ }^{4}$ The question is how to select the appropriate decision-making measures and find the most influent factors of stock prices? According to Glen (2005, p. 308) managers will not be able to define the consequences of their managerial decisions without being aware of these factors. One possible solution is the concept of residual income as a performance measure and valuation tool. The concept lies on the economic reasoning that profitability adds to equity capital. The concept was introduced in early $1920 \mathrm{~s}$; however, it was not frequently used since, despite its interesting underlying. The stimulus for its return to the management financial horizon was Stewart's publication in 1991 in which the authors presented their "modernized" version of residual income: Economic Value Added or EVA ${ }^{\circledR}$ (Christensen, Feltham, and $\mathrm{Wu}, 2002)$. According to this model, a firm's positive net income (as accounting category) does not necessarily imply that a firm is creating value for its owners.

The Residual Income Valuation model (RIV) is an appealing approach and was getting attention in the accounting literature. The reason is its apparent ability to give a constructive role to accounting data in equity valuation. By contrast, valuation based on the future cash flows suggests a general irrelevance of future earnings and other accounting data (Ohlson, 2005, p. 323). In addition, Jamin (2005) found that in contrast to the theoretical prediction, the performance of the RIV model is not much better than simple ratios analysis. But, according to Halsey (2001, p. 258) the RIV model is theoretically equivalent to the model of free cash flows that belongs to equity capital. Both models are derived from the dividend discount model. Dechow, Hutton, and Sloan (1999) believe that despite the ambiguous empirical support, the model provides a useful framework for empirical research for three main reasons: 1) it provides a unifying framework for a large number of previous 'ad hoc' valuation models using book value, earnings and shortterm forecasts of earnings. 2) Second, the model provides a basic framework upon which subsequent research can build, and 3) the focus of the model on the relation between current information variables and future abnormal earnings is heuristically appealing. Cheng (2005) found out that integrating the factors that increase abnormal ROE into the residual income valuation model significantly increases its explanatory power. The research of Lundholm and O'Keefe (2001) examined why practitioners and researchers get different estimates of equity value, when they use a discounted cash flow model versus a residual income model. According to the authors, both models are derived from the same underlying assumption, that price is the present value of expected future net dividends discounted at the cost of equity capital. Unfortunately, in practice and in research they frequently yield different estimates. Ludholm and O'Keefe argue that previous studies were not correctly implemented using inconsistent assumptions that lead to large differences in value. They demonstrate that properly applied, both models yield identi-

3 If we measure the efficiency of all capital sources (debt and equity) the proper rate of return to take into account is the weighted average cost on capital (WACC).

$4 \quad$ This means maximizing the value of firms' assets, which leads to maximizing the equity value. For the purpose/objectives of the firm look in Brealey et al. (2012), Brigham and Ehrhardt (2017), Arnold (2013), Damodaran (2016), and other financial literature. 
cal valuations for all firms in all years. The research of Biddle, Chen, and Zhang (2001) tested the predictions against the linear information dynamics proposed by Ohlson (1995) and Feltham and Ohlson (1996), with supportive results. Their findings are important for further developments of the links between firm's value and the economics of value creation. Balachandran and Mohanram (2012) studied the association of residual income and invested capital with future earnings. They found that: 1) earnings growth associated with high growth in residual income is more likely to be persistent while earnings growth associated with high growth in invested capital is more likely to reverse. 2) Future returns are positively associated with growth in residual income and negatively associated with growth in invested capital. Based on their findings they argue that residual income allows investors understand and evaluate different sources of earnings growth.

\section{THE MODEL}

Residual income at present time can be estimated according to the following equation (Halsey, 2001, p. 258):

$$
R I_{0}=E_{0}-r \cdot B V_{-1}
$$

Where $R I_{0}$ is the present value of residual income, $E_{0}$ is the present value of net income, $r$ is the required return of equity capital, $B V_{-1}$ is the book value of equity capital in the previous period. The value of expected residual incomes can be expressed as:

$$
\frac{R I_{1}}{r}=\frac{E_{1}-r \cdot B V_{0}}{r}
$$

The value of equity capital with constant growing expected residual income can be calculated as:

$$
V_{0}=B V_{0}+\frac{R I_{1}}{r-g_{R I}}=\frac{E_{1}-r \cdot B V_{0}}{r-g_{R I}}
$$

Where $R I_{l}$ is the expected residual income, $E_{l}$ is the expected net income, $B V_{0}$ is the book value of equity capital, and $g_{R I}$ is the expected growth rate of residual incomes. Following the assumption that a company adds value for its owners, the residual income has to be positive. For the purpose of our empirical analysis, we will express residual income in relative terms relative residual income) taking into account the average book value of equity capital in a year. The equation is the following:

$$
R I_{t}(\%)=\frac{R I_{t}}{\frac{B V_{t-1}+B V_{t}}{2}}=\frac{E_{t}-r_{t} \frac{B V_{t-1}+B V_{t}}{2}}{\frac{B V_{t-1}+B V_{t}}{2}}=\frac{E_{t}}{\frac{B V_{t-1}+B V_{t}}{2}}-r_{t}
$$

If we substitute with ROE:

$$
R I_{t}(\%)=R O E_{t}-r_{t}
$$

Where $R O E_{t}$ is return on equity capital for year $t, R I_{t}$ is the net income for year $t, B V_{t-1}$ is the book value of equity capital at the end of the year $t-1, E_{t}$ is the net income for year $t, B V_{t}$ is the book value of equity capital at the end of the year $t$, and $r_{t}$ is the cost of equity capital for year $t$. 


\section{REQUIRED RETURN ON EQUITY CAPITAL}

The required return on equity capital is the essential parameter for our analysis. Required return on equity was estimated using the Capital Asset Pricing Model, or CAPM. ${ }^{5}$ According to CAPM a required return on equity is calculated as follows:

$$
r_{i}=r_{f}+\beta_{i} \cdot\left(r_{m}-r_{f}\right)
$$

Where $r_{i}$ is a required return on equity, $r_{f}$ is the risk-free rate, $\beta_{i}$ is the beta coefficient (measure of market risk), $r_{m}$ is the market return on equity, and the $\left(r_{m}-r_{f}\right)$ is the market risk premium.

Despite a wide set of more or less complicated models for the required return of equity estimation the most widely used model in practice is the CAPM. However, we must understand that the model is based on very strong assumptions. Blitz, Falkenstein, and Van Vliet (2014) divide the CAPM assumptions in the following groups: 1) There are no constraints (e.g., on leverage and short-selling); 2) Investors are risk averse, maximize the expected utility of absolute wealth, and care only about the mean and variance of return; 3) There is only one period; 4) Information is complete and rationally processed; and 5) Markets are perfect (i.e. all assets are perfectly divisible and perfectly liquid, there are no transaction costs, there are no taxes, and all investors are price takers). Despite being the most used model in practice the discussion on the validity of the CAPM is still undergoing. ${ }^{6}$ The skepticism on the validity of the CAPM was among others also expressed by Fama and French (1992). In their paper, they demonstrated that the CAPM does not explain a substantial fraction of market returns. Despite some very strong and unrealistic assumptions, due to its "simplicity", CAPM is a widely used model for determining the required return on equity (Brigham and Ehrhardt, 2011; Wright, Mason, and Miles, 2003).

\section{REQUIRED RETURN ON EQUITY CAPITAL ESTIMATION}

Using the CAPM in practice is all other than straightforward. One must estimate the input variables which is a challenging task especially on a capital market like Slovenian. ${ }^{7}$ The estimation of a risk-free rate, beta, and market risk premium is not simple and we do not have an ideal practical solution.

For our empirical analysis, we used all data from the U.S. market as we found coverage for all the analysed years. Data from different markets were not included to prevent additional bias. We retrieved the unlevered beta from Damodaran database (2019) for the Hotel/Gaming industry. To estimate a market risk premium, we followed two approaches. As a base, we assumed a long-term sustainable market risk premium of $4 \%{ }^{8}$ to which we added a country risk premium for each year. We calculated a country risk premium as the relative volatility of stocks and bonds market, multiplied with the average of credit-rating estimated default swap ${ }^{9}$, and a credit

$5 \quad$ The model was independently developed by Treynor (1961, 1962), Sharpe (1964), Lintner (1965a,b), and Mossin (1966).

$6 \quad$ For criticism in relation to the CAPM look in McGoun (1993), and Fernandez (2015).

7 The Slovenian capital market is not efficient. It is small, with only nine actively traded stocks in the first quotation, and twenty stocks traded in the standard quotation. Total market capitalization of Ljubljana Stock Exchange (Ljubljana Stock Exchange, 2017) at the end of year 2017 was 5.3 billion Euros, the annual turnover around 350 million Euros. The fact is that it is not possible to assess the risk from market data.

8 According to Brigham and Ehrhardt (2017) most analysts use a market risk premium in the range of $4 \%$ to $7 \%$.

9 Data from Bloomberg (2019). 
default swap for Slovenia net of United States credit default swap. Adding a country risk premium in the CAPM is not theoretically supported ${ }^{10}$, but is widely used in practice. The rationale for our approach is that a long-term market risk premium is stable over time, with short-term fluctuations in the investor's risk aversion. We count for these fluctuations, adding a country risk premium. Greater the aversion to risk, greater is the market risk premium. In the second approach we used the average of the implied market risk premium estimations in the last ten years, which we calculate for each year. The fluctuations of the risk aversion are incorporated in the implied market risk premium. In this second approach we also assumed that investors could sweep away country specific risk with global diversification, and consequently a country risk is not rewarded. We retrieved the data for all variables that we estimated (the market risk premium, implied market risk premium and country risk premium) from Damodaran (2019). We estimated a long-term equilibrium risk free rate of return as the average yield to maturity of U.S. indexed bond ${ }^{11}$ for the last ten years (monthly data). We added the expected inflation of $2 \%$ taking into account the European Central Bank (2019) target inflation rate. ${ }^{12}$. We got the data for the market (systematic) risk measure - beta from the Damodaran database (2019) for the U.S. Hotel/Gaming industry. The betas are estimated by regressing weekly returns on stock against the local index using 5-years of data. Damodaran (2019) uses a composite of the two-year regression beta and the five-year regression beta, weighting the former $2 / 3^{\text {rd }}$ and the latter $1 / 3^{\text {rd }}$. We use the unlevered beta, which we levered for each firm with the Hamada equation as following:

$$
\beta_{\mathrm{l}}=\beta_{\mathrm{u}} \cdot\left[1+(1-\mathrm{T}) \cdot\left(\frac{\mathrm{w}_{\mathrm{d}}}{\mathrm{w}_{\mathrm{s}}}\right)\right]
$$

Where: $\beta_{l}$ is the leveraged beta, $\beta_{u}$ is the unleveraged beta, $w_{d}$ and $w_{s}$ weights of equity and debt capital, where $w_{d}+w_{s}=1, T$ is the corporate tax rate. The used end estimated parameters for the CAPM are presented in Table 1 . The leveraged beta is greater for small firms ${ }^{13}$ due to higher leverage.

Table 1. Used and estimated CAPM parameters

\begin{tabular}{|l|c|c|c|c|c|c|c|c|c|c|}
\hline \multicolumn{1}{|c|}{ Variable/Year } & $\mathbf{2 0 0 9}$ & $\mathbf{2 0 1 0}$ & $\mathbf{2 0 1 1}$ & $\mathbf{2 0 1 2}$ & $\mathbf{2 0 1 3}$ & $\mathbf{2 0 1 4}$ & $\mathbf{2 0 1 5}$ & $\mathbf{2 0 1 6}$ & $\mathbf{2 0 1 7}$ & $\mathbf{2 0 1 8}$ \\
\hline Unlevered beta US (Hotel/Gaming) & 1.00 & 1.24 & 1.20 & 1.21 & 0.78 & 0.80 & 0.65 & 0.64 & 0.72 & 0.68 \\
\hline Nominal risk-free rate (\%) & 4.65 & 4.43 & 4.20 & 3.90 & 3.69 & 3.55 & 3.42 & 3.24 & 3.07 & 2.93 \\
\hline Estimated market risk premium (\%) & 4.67 & 4.68 & 5.39 & 6.51 & 6.67 & 6.24 & 6.10 & 5.97 & 5.57 & 5.65 \\
\hline Levered beta BF & 1.55 & 1.98 & 1.97 & 2.01 & 1.32 & 1.40 & 1.03 & 0.98 & 1.10 & 0.96 \\
\hline Levered beta MF & 1.61 & 2.05 & 1.93 & 2.01 & 1.15 & 1.40 & 0.88 & 0.92 & 1.10 & 1.06 \\
\hline Levered beta SF & 2.31 & 2.86 & 2.75 & 2.62 & 1.57 & 1.51 & 1.12 & 1.12 & 1.30 & 1.09 \\
\hline Levered beta of all firms & 1.61 & 2.06 & 2.01 & 2.06 & 1.30 & 1.41 & 0.99 & 0.98 & 1.12 & 1.00 \\
\hline
\end{tabular}

Legend: BF is for large firms, MF is for medium-sized firms, SF is for small firms

Sources: Damodaran, 2019; FRED, 2019; European Central Bank, 2019; GVIN, 2019; Bloomberg, 2019; own calculations

Table 2 presents the estimated parameters for all aggregates and in total. We estimated the beta for the aggregates of large, medium-sized, and small firms, and the aggregate of all the firms in our sample that represent the Slovenian hotel industry. We can see that small firms have greater required return on equity capital, as they have greater aggregate financial leverage. We did not use any additional premium for small firms.

$10 \quad$ For more details see Kruschwitz, Löffler, and Mandl (2012).

11 Data from FRED (2019).

12 The European Central Bank (2019) aims at inflation rates of below, but close to 2\% over the medium term.

13 All the parameters, variables, and ratios that we used in our analysis for the groups of large, medium-sized, small and all firms are calculated summing the data from the income statements and balance sheets of firms allocated in the group. 
Table 2. The estimated required return on equity capital for the Slovenian hotel industry

\begin{tabular}{|l|c|c|c|c|c|c|c|c|c|c|}
\hline $\begin{array}{c}\text { Required return on equity capital in } \\
\text { \%/Year }\end{array}$ & $\mathbf{2 0 0 9}$ & $\mathbf{2 0 1 0}$ & $\mathbf{2 0 1 1}$ & $\mathbf{2 0 1 2}$ & $\mathbf{2 0 1 3}$ & $\mathbf{2 0 1 4}$ & $\mathbf{2 0 1 5}$ & $\mathbf{2 0 1 6}$ & $\mathbf{2 0 1 7}$ & $\mathbf{2 0 1 8}$ \\
\hline Large firms & 11,86 & 13,68 & 14,80 & 17,01 & 12,47 & 12,26 & 9,68 & 9,10 & 9,18 & 8,37 \\
\hline Medium-sized firms & 12,16 & 14,04 & 14,59 & 16,98 & 11,37 & 12,29 & 8,75 & 8,73 & 9,21 & 8,91 \\
\hline Small firms & 15,41 & 17,84 & 19,02 & 20,94 & 14,20 & 12,95 & 10,23 & 9,94 & 10,29 & 9,08 \\
\hline All firms & 12,16 & 14,09 & 15,04 & 17,32 & 12,35 & 12,35 & 9,44 & 9,09 & 9,32 & 8,61 \\
\hline
\end{tabular}

Sources: Damodaran, 2019; FRED, 2019; European Central Bank, 2019; GVIN, 2019; Bloomberg, 2019; own calculations

According to Table 2 we can see that the cost of equity capital decreased significantly from 2012 to 2018 . This was mostly caused by the decreasing value of beta coefficient (Table 1).

\section{FIRMS' DATA USED}

The data was collected from the balance sheet and statement of income for Slovenian firms for the period 2008-2018 for all the large, medium-sized, and small firms in the hotel industry. We aggregated the data all together and in groups of large, medium-sized, and small firms. The division between large, medium-sized, and small firms is in accordance with the Slovenian corporate law. The data was obtained from the GVIN financial database. The primary collection of data is performed by the Agency of the Republic of Slovenia for Public Legal Records and Related Services (AJPES). Our sample includes 81 firms. For some firms' data was not available for all the observed years (some firms did not operate in the whole analyzed period). We used all available data for the observed year. We excluded from our further analysis all the firms with negative equity capital. The data for the groups of Slovene hotel firms are presented in Table 3.

Table 3. Financial data for groups of Slovenian hotel industry firms

\begin{tabular}{|l|c|c|c|c|c|c|c|c|c|c|c|}
\hline $\begin{array}{l}\text { In 1000 } \\
\text { euros/Year }\end{array}$ & $\mathbf{2 0 0 8}$ & $\mathbf{2 0 0 9}$ & $\mathbf{2 0 1 0}$ & $\mathbf{2 0 1 1}$ & $\mathbf{2 0 1 2}$ & $\mathbf{2 0 1 3}$ & $\mathbf{2 0 1 4}$ & $\mathbf{2 0 1 5}$ & $\mathbf{2 0 1 6}$ & $\mathbf{2 0 1 7}$ & $\mathbf{2 0 1 8}$ \\
\hline $\begin{array}{l}\text { Net income } \\
\text { LF }\end{array}$ & 8.633 & -10.004 & -14.507 & -17.700 & -31.760 & -28.139 & -45.340 & 1.165 & 16.103 & 15.844 & 21.205 \\
\hline $\begin{array}{l}\text { Net income } \\
\text { MF }\end{array}$ & -6.699 & -9.510 & -9.722 & -9.275 & -36.151 & -5.368 & -12.963 & -8.721 & -617 & 6.007 & -1.373 \\
\hline $\begin{array}{l}\text { Net income } \\
\text { SF }\end{array}$ & 1.087 & 1.548 & -186 & 1.597 & 2.755 & 3.815 & 3.091 & 3.292 & 3.459 & 3.369 & 5.697 \\
\hline Total & 3.022 & -17.966 & -24.414 & -25.379 & -65.156 & -29.692 & -55.212 & -4.264 & 18.945 & 25.220 & 25.529 \\
\hline $\begin{array}{l}\text { Equity } \\
\text { capital LF }\end{array}$ & 404.821 & 426.407 & 393.707 & 435.162 & 404.012 & 366.310 & 320.505 & 337.332 & 349.192 & 397.552 & 435.641 \\
\hline $\begin{array}{l}\text { Equity } \\
\text { capital MF }\end{array}$ & 171.003 & 172.830 & 168.527 & 175.742 & 153.308 & 146.463 & 142.334 & 195.677 & 182.146 & 192.400 & 189.521 \\
\hline $\begin{array}{l}\text { Equity } \\
\text { capital SF }\end{array}$ & 36.370 & 39.933 & 45.141 & 45.663 & 48.542 & 52.661 & 60.951 & 67.857 & 75.866 & 81.466 & 96.181 \\
\hline Total & 612.194 & 639.170 & 607.374 & 656.567 & 605.862 & 565.434 & 523.791 & 600.866 & 607.203 & 671.418 & 721.343 \\
\hline Debt LF & 270.016 & 280.849 & 281.694 & 334.805 & 323.802 & 302.767 & 288.158 & 236.067 & 224.311 & 251.427 & 218.059 \\
\hline Debt MF & 119.596 & 127.011 & 133.086 & 128.192 & 122.010 & 83.577 & 128.850 & 81.609 & 95.954 & 122.933 & 126.683 \\
\hline Debt SF & 58.571 & 62.858 & 71.242 & 70.974 & 68.058 & 64.548 & 64.820 & 58.820 & 68.798 & 78.657 & 69.378 \\
\hline Total & 448.183 & 470.718 & 486.022 & 533.971 & 513.870 & 450.892 & 481.827 & 376.495 & 389.064 & 453.017 & 414.120 \\
\hline
\end{tabular}

Legend: LF is for large firms, MF is for medium-sized firms, SF is for small firms, total is for all firms.

Source: GVIN, 2019; own calculations 


\section{RESULTS AND DISCUSSION}

The described methodology (see chapter 4 and 5) was applied on data described in chapter 6 . ROE for the aggregate Slovenian hotel industry was negative until 2015 (Table 4 and Figure 1), mostly due to the negative income of some large and medium-sized firms. Small firms had a positive ROE for all the observed years, except for the year 2010. We have also performed the nonparametric Kruskal-Wallis test for differences of ROE between hotel firms of different sizes (for the entire analyzed period). The difference was highly significant (adj. $\mathrm{p}=0.001$ ) between medium-sized and small firms, and highly significant (adj. $\mathrm{p}=0.018$ ) between large and small firms. The difference in ROE between large and medium-sized firms was not significant.

Table 4. Return on equity (ROE) for groups of Slovenian hotel industry firms for the period 2009-2018

\begin{tabular}{|l|c|c|c|c|c|c|c|c|c|c|c|}
\hline $\begin{array}{c}\text { ROE in } \\
\text { \%/Year }\end{array}$ & $\mathbf{2 0 0 9}$ & $\mathbf{2 0 1 0}$ & $\mathbf{2 0 1 1}$ & $\mathbf{2 0 1 2}$ & $\mathbf{2 0 1 3}$ & $\mathbf{2 0 1 4}$ & $\mathbf{2 0 1 5}$ & $\mathbf{2 0 1 6}$ & $\mathbf{2 0 1 7}$ & $\mathbf{2 0 1 8}$ & Median \\
\hline ROE LF & $-2,41$ & $-3,54$ & $-4,27$ & $-7,57$ & $-7,31$ & $-13,20$ & 0,35 & 4,69 & 4,24 & 5,09 & $-2,97$ \\
\hline ROE MF & $-5,53$ & $-5,70$ & $-5,39$ & $-21,97$ & $-3,58$ & $-8,98$ & $-5,16$ & $-0,33$ & 3,21 & $-0,72$ & $-5,27$ \\
\hline ROE SF & 4,06 & $-0,44$ & 3,52 & 5,85 & 7,54 & 5,44 & 5,11 & 4,81 & 4,28 & 6,41 & 4,96 \\
\hline ROE AF & $-2,87$ & $-3,92$ & $-4,02$ & $-10,32$ & $-5,07$ & $-10,14$ & $-0,76$ & 3,14 & 3,94 & 3,67 & $-3,39$ \\
\hline
\end{tabular}

Legend: $\mathrm{LF}$ is for large firms, MF is for medium-sized firms, SF is for small firms, AF is for all firms

Source: GVIN, 2019; own calculations

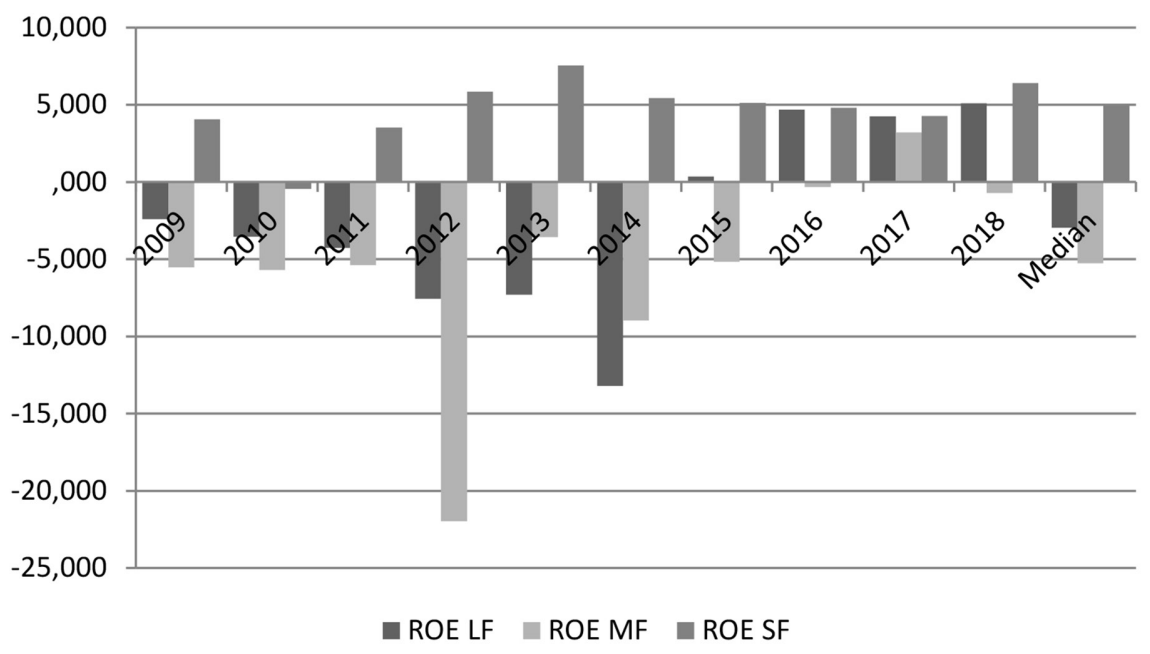

Legend: LF is for large firms, MF is for medium-sized firms, $\mathrm{SF}$ is for small firms, AF is for all firms

Figure 1. Return on equity (ROE) for groups of Slovenian hotel industry firms for the period 2009-2018

Source: GVIN, 2019; own calculations

The relative residual income (in \%) is negative in the entire analyzed period (Table 5 and Figure 2). These results simply indicate that in aggregate capital owners/investors in Slovenian hotel industry firms lose value on their invested equity capital. The results improved in the last few years due to the increasing ROE and the decreasing required return on equity, but relative residual income is still not positive. We have performed also the non-parametric Kruskal-Wallis test for differences between relative residual income of groups of large, medium-sized, and small firms in the analyzed period. The difference resulted not significant (adj. $p=0.127$ ). 
Table 5. Relative residual income (ROE-r) for groups of Slovenian hotel industry firms for the period 2009-2018

\begin{tabular}{|l|c|c|c|c|c|c|c|c|c|c|c|}
\hline $\begin{array}{c}\text { ROE-r in } \\
\text { \%/Year }\end{array}$ & $\mathbf{2 0 0 9}$ & $\mathbf{2 0 1 0}$ & $\mathbf{2 0 1 1}$ & $\mathbf{2 0 1 2}$ & $\mathbf{2 0 1 3}$ & $\mathbf{2 0 1 4}$ & $\mathbf{2 0 1 5}$ & $\mathbf{2 0 1 6}$ & $\mathbf{2 0 1 7}$ & $\mathbf{2 0 1 8}$ & Median \\
\hline ROE-r LF & $-14,27$ & $-17,22$ & $-19,07$ & $-24,58$ & $-19,78$ & $-25,47$ & $-9,33$ & $-4,41$ & $-4,94$ & $-3,28$ & $-15,75$ \\
\hline ROE-r MF & $-17,69$ & $-19,74$ & $-19,98$ & $-38,95$ & $-14,95$ & $-21,27$ & $-13,91$ & $-9,06$ & $-6,00$ & $-9,63$ & $-16,32$ \\
\hline ROE-r SF & $-11,35$ & $-18,28$ & $-15,50$ & $-15,09$ & $-6,66$ & $-7,50$ & $-5,12$ & $-5,12$ & $-6,01$ & $-2,67$ & $-7,08$ \\
\hline ROE-r AF & $-15,04$ & $-18,01$ & $-19,05$ & $-27,64$ & $-17,42$ & $-22,49$ & $-10,20$ & $-5,96$ & $-5,38$ & $-4,94$ & $-16,23$ \\
\hline
\end{tabular}

Sources: Damodaran, 2019; FRED, 2019; European Central Bank, 2019;

GVIN, 2019; Bloomberg, 2019; own calculations

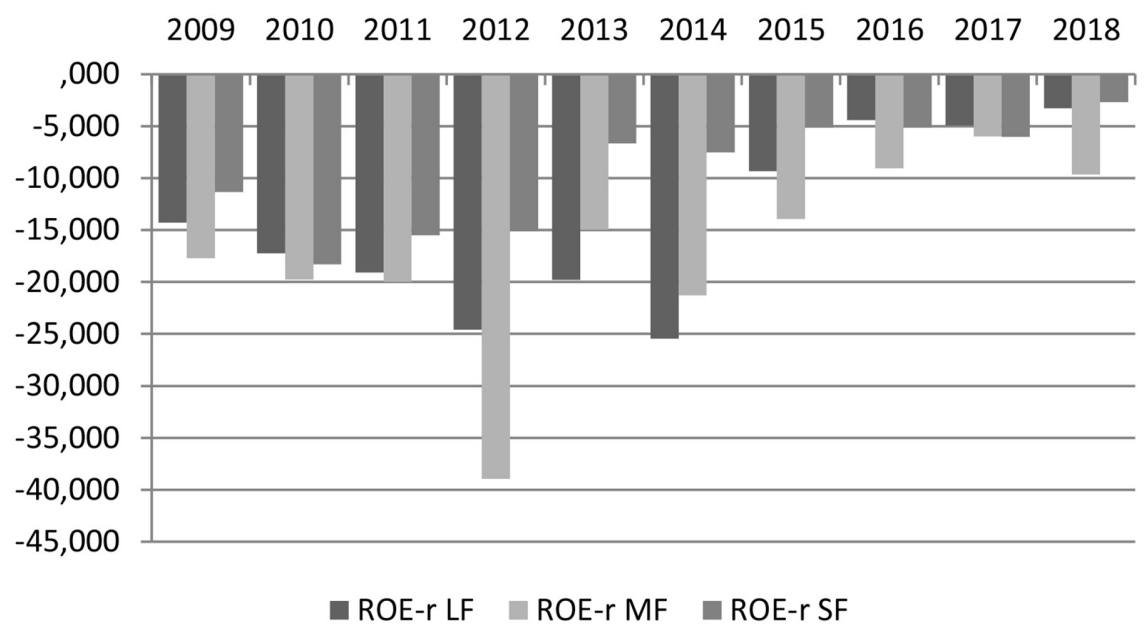

Figure 2. Relative residual income (ROE-r) for groups of Slovenian hotel industry firms for the period 2009-2018

Sources: Damodaran, 2019; FRED, 2019; European Central Bank, 2019; GVIN, 2019; Bloomberg, 2019; own calculations

We have also calculated the changing rate of the required return on equity capital, ROE, and the relative residual income. The results are presented in the Table 6 and Figures 3, 4 and 5. We see that the greatest improvement occurred in 2015, due to the increased profitability and the decreased required return on equity, mostly due to the decreased risk measure beta (see Table 1). Beta decreased for two reasons: 1) due to the decrease of the unlevered beta (lower estimated risk for U.S. Hotel/Gaming industry), and 2) due to the financial deleveraging of Slovenian hotel firms and consequently a lower $\mathrm{n}$ levered beta.

Table 6. The rate of change of the required return on equity capital, the rate of change of

$\mathrm{ROE}$, and the rate of change of the relative residual income

\begin{tabular}{|l|c|c|c|c|c|c|c|c|c|}
\hline \multicolumn{1}{|c|}{ In \% points } & $\mathbf{2 0 1 0}$ & $\mathbf{2 0 1 1}$ & $\mathbf{2 0 1 2}$ & $\mathbf{2 0 1 3}$ & $\mathbf{2 0 1 4}$ & $\mathbf{2 0 1 5}$ & $\mathbf{2 0 1 6}$ & $\mathbf{2 0 1 7}$ & $\mathbf{2 0 1 8}$ \\
\hline$\Delta$ r AF & 1,93 & 0,95 & 2,28 & $-4,97$ & 0,00 & $-2,91$ & $-0,35$ & 0,23 & $-0,72$ \\
\hline$\Delta$ ROE AF & $-1,05$ & $-0,10$ & $-6,31$ & 5,25 & $-5,07$ & 9,38 & 3,89 & 0,81 & $-0,28$ \\
\hline$\Delta$ ROE-r AF & $-2,97$ & $-1,05$ & $-8,59$ & 10,23 & $-5,07$ & 12,29 & 4,25 & 0,58 & 0,44 \\
\hline
\end{tabular}

Sources: Damodaran, 2019; FRED, 2019; European Central Bank, 2019; GVIN, 2019; Bloomberg, 2019; own calculations 


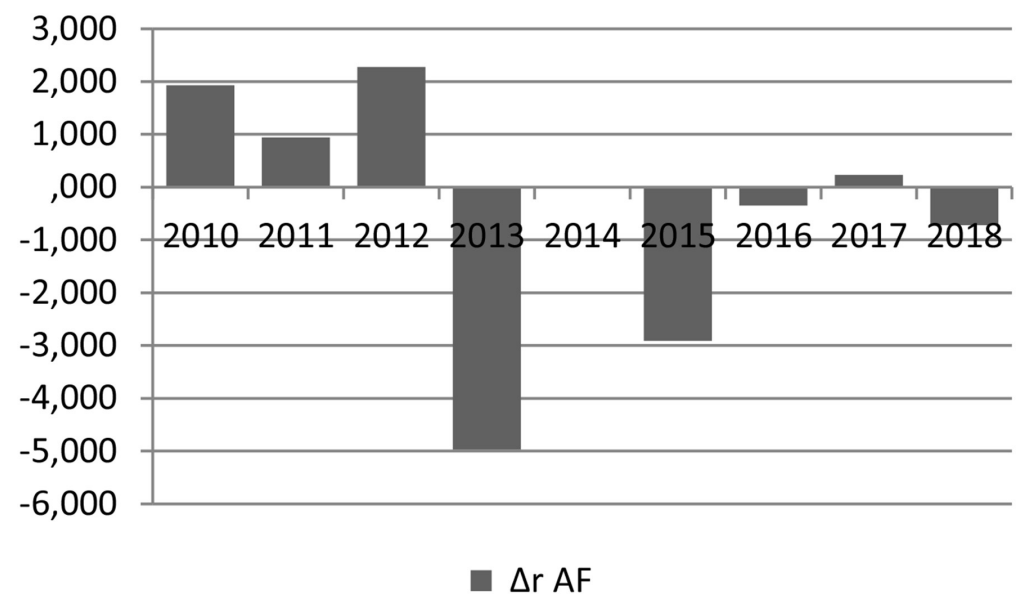

Figure 3. The rate of change of the required return on equity capital Sources: Damodaran, 2019; FRED, 2019; European Central Bank, 2019; GVIN, 2019; Bloomberg, 2019; own calculations

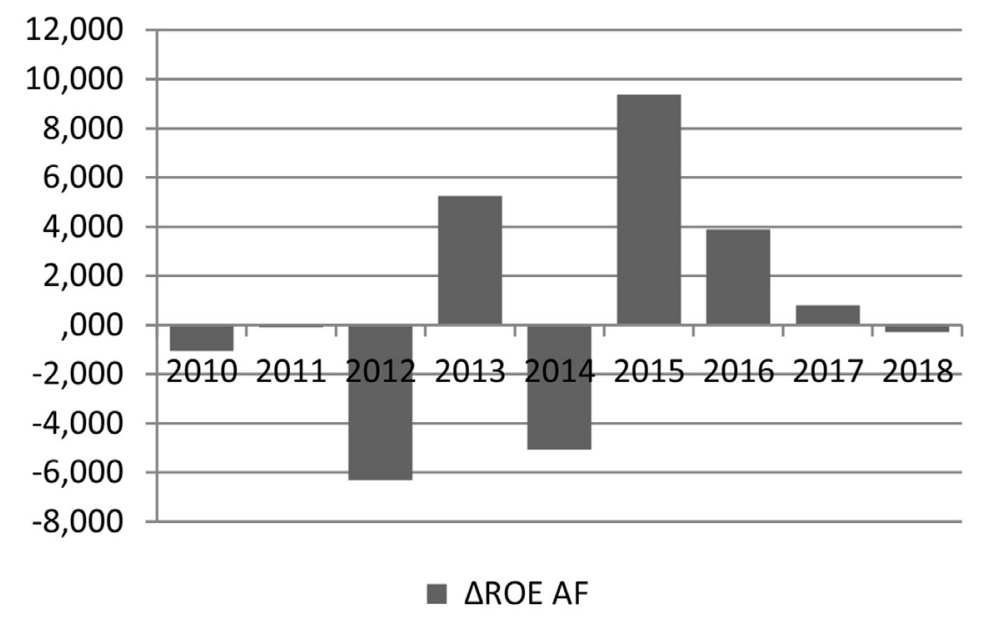

Figure 4. The rate of change of ROE

Sources: Damodaran, 2019; FRED, 2019; European Central Bank, 2019;

GVIN, 2019; Bloomberg, 2019; own calculations

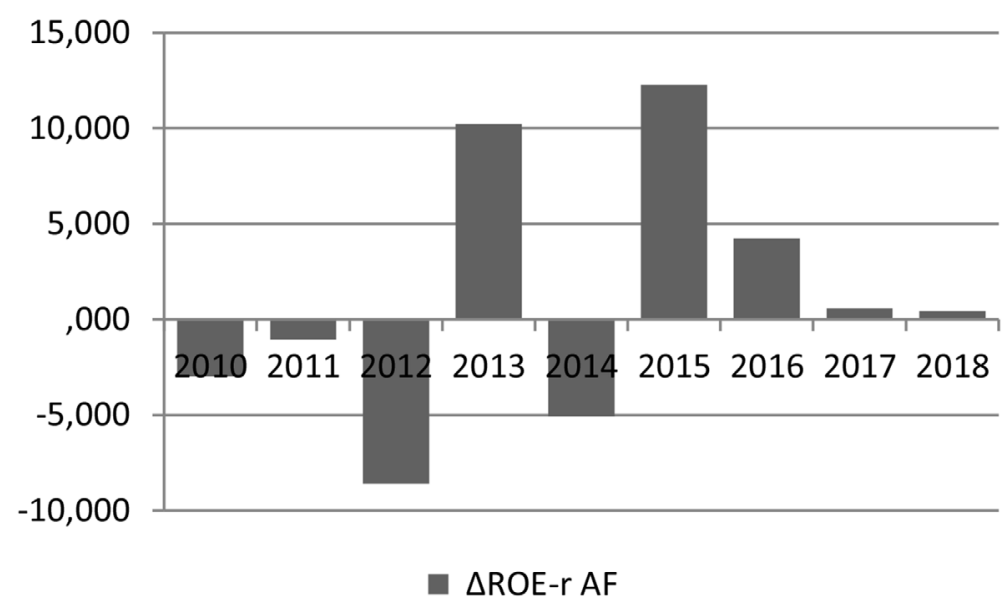

Figure 5. The rate of change of the relative residual income Sources: Damodaran, 2019; FRED, 2019; European Central Bank, 2019; GVIN, 2019; Bloomberg, 2019; own calculations 
An obvious question that arises after thorough examination of the results above is, how come that the hotel industry did not earn enough to compensate a required return of equity for their owners? We have also done a market analysis comparing the results with all Slovenian companies. We are also interested if our estimated required cost of capital was too high and maybe the primary reason of poor results. In Table 7 and Figure 6 we present the ROE of all Slovenian firms and the ROE of all the analysed firms. We can see from the Table 7 that the ROE of all Slovenian firms is much higher in all the observed years.

Table 7. ROE of all Slovenian firms and ROE of all analysed firms

\begin{tabular}{|l|c|c|c|c|c|c|c|c|c|c|c|}
\hline $\begin{array}{l}\text { Aggregate } \\
\text { ROE in \% }\end{array}$ & $\mathbf{2 0 0 9}$ & $\mathbf{2 0 1 0}$ & $\mathbf{2 0 1 1}$ & $\mathbf{2 0 1 2}$ & $\mathbf{2 0 1 3}$ & $\mathbf{2 0 1 4}$ & $\mathbf{2 0 1 5}$ & $\mathbf{2 0 1 6}$ & $\mathbf{2 0 1 7}$ & $\mathbf{2 0 1 8}$ & Median \\
\hline $\begin{array}{l}\text { ROE of all } \\
\begin{array}{l}\text { Slovenian } \\
\text { firms }\end{array}\end{array}$ & 1,51 & $-0,69$ & 1,21 & 0,88 & 0,45 & 2,37 & 4,86 & 7,79 & 8,29 & 9,06 & 1,94 \\
\hline $\begin{array}{l}\text { ROE of } \\
\begin{array}{l}\text { Hotel } \\
\text { industry }\end{array}\end{array}$ & $-2,87$ & $-3,92$ & $-4,02$ & $-10,32$ & $-5,07$ & $-10,14$ & $-0,76$ & 3,14 & 3,94 & 3,67 & $-3,39$ \\
\hline Difference & 4,38 & 3,23 & 5,23 & 11,20 & 5,52 & 12,51 & 5,62 & 4,65 & 4,35 & 5,43 & \\
\hline
\end{tabular}

Source: GVIN, 2019; own calculations

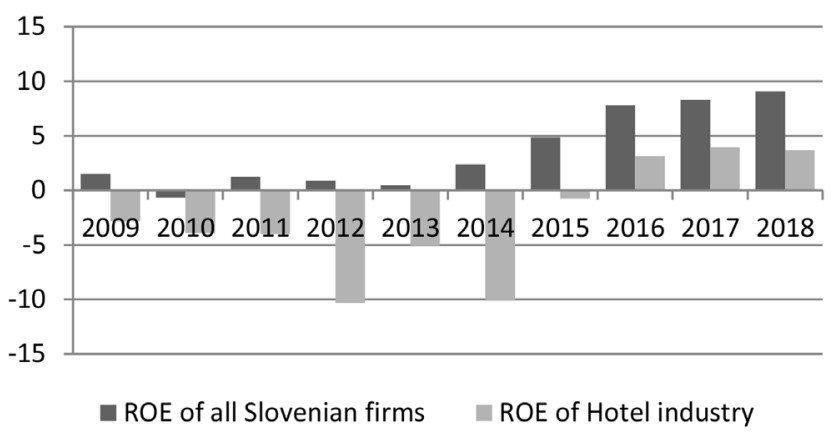

Figure 6. ROE of all Slovenian firms and ROE of all analysed firms

Source: GVIN, 2019; own calculations

We have also compared the required return on equity for all the Slovenian firms and for the Slovenian hotel industry (Table 8 and Figure 7). We used the theoretically supported assumption that the market beta equals 1 . As we can see, the required return on equity is higher for the hotel industry in all the years, except the years 2015 and 2016 when it was slightly below the required return on equity for all Slovenian firms. The difference is logical due to differences in the risk (beta).

Table 8. The required return on equity capital of all Slovenian firms (beta=1) and required return on equity for the hotel industry

\begin{tabular}{|l|c|c|c|c|c|c|c|c|c|c|c|}
\hline $\begin{array}{l}\text { Required return on } \\
\text { equity capital in \% }\end{array}$ & $\mathbf{2 0 0 9}$ & $\mathbf{2 0 1 0}$ & $\mathbf{2 0 1 1}$ & $\mathbf{2 0 1 2}$ & $\mathbf{2 0 1 3}$ & $\mathbf{2 0 1 4}$ & $\mathbf{2 0 1 5}$ & $\mathbf{2 0 1 6}$ & $\mathbf{2 0 1 7}$ & $\mathbf{2 0 1 8}$ & Median \\
\hline $\begin{array}{l}\text { Required return on } \\
\text { equity capital of all } \\
\text { Slovenian firms }\end{array}$ & 9,31 & 9,11 & 9,59 & 10,41 & 10,37 & 9,79 & 9,52 & 9,21 & 8,64 & 8,59 & 9,41 \\
\hline $\begin{array}{l}\text { Required return on } \\
\text { equity capital of Slo- } \\
\text { venian hotel industry }\end{array}$ & 12,16 & 14,09 & 15,04 & 17,32 & 12,35 & 12,35 & 9,44 & 9,09 & 9,32 & 8,61 & 12,26 \\
\hline Difference & 2,85 & 4,98 & 5,45 & 6,91 & 1,98 & 2,56 & $-0,07$ & $-0,12$ & 0,69 & 0,02 & \\
\hline
\end{tabular}

Sources: Damodaran, 2019; FRED, 2019; European Central Bank, 2019;

GVIN, 2019; Bloomberg, 2019; own calculations 


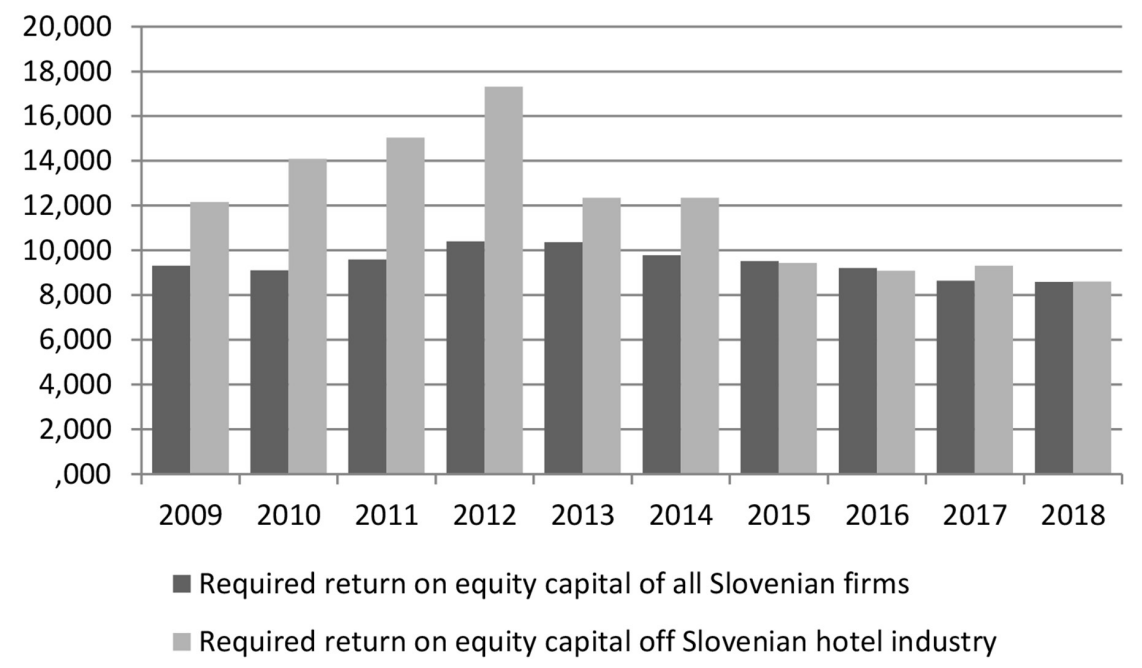

Figure 7. The required return on equity capital of all Slovenian firms (beta=1) and required return on equity for the hotel industry

Sources: Damodaran, 2019; FRED, 2019; European Central Bank, 2019;

GVIN, 2019; Bloomberg, 2019; own calculations

We have also estimated the accounting beta to assess the undiversifiable (systematic) risk of the hotel industry. We examined whether the result is in line with the used market betas from the U.S. market that we levered according to the debt of the Slovenian hotel industry. Levered betas show that the hotel industry is riskier than the market portfolio in all the observed years except the years 2015 and 2016 in which were slightly below the market risk. Accounting betas are calculated with accounting data. The problem of accounting betas' estimation is that earnings are not reported so frequently (once, or in the best case four times per year) in comparison to market data. Strict adherents to market data are contrary to accounting measures for more reasons. But, especially during the recent financial crisis investors realized that financial markets do not provide complete and reliable information, so that absolute faith in them is unjustified and support the necessity of accounting-based risk measures (Toms, 2012). We use the accounting beta as a complementary measure to give additional explanation power to our results. For the calculation, we have done a linear regression of aggregate Slovenian hotel industry firms ROE, as a dependent variable, and Slovenian firms ROE, as the explanatory variable. We apply the following regression equation:

$$
R O E_{H I}=\alpha+\beta \cdot R O E_{M}+\varepsilon
$$

Where $R O E_{H I}$ is the aggregated return on equity for the Slovenian hotel industry in year $t, \alpha$ is the intercept, $\beta$ is the accounting systematic risk measure, $R O E_{M}$ is the aggregated return on equity of all Slovenian companies, and $\varepsilon$ is the error term. The estimated accounting beta was 1.17. Despite the short time series of data, the explanatory variable coefficient was highly significant at $\mathrm{p}=0.004^{14}$, and $\mathrm{R}$ squared $=0.63$. That means that we can explain $62 \%$ of the variability of the hotel industry ROE with all Slovenian firms ROE. The results show that in the analysed period, the hotel industry is riskier and requires a higher required return on equity, which is in line with the results in Table 8 (Median), and the levered market betas in Table 1.

$14 \quad$ Mainly due to the fact that we used hotel industry aggregated data. Industry betas are usually calculated from market returns data with a regression for each firm separately and then averaged within the industry. For the sake of our comparison the method we used is correct. 
But, unfortunately the ROE of the hotel industry is lower than the Slovenian firms ROE (see Table 7) which is relatively speaking not a proper compensation for the risk.

Table 9. Relative residual income for Slovenian hotel industry firms and all Slovenian firms

\begin{tabular}{|l|c|c|c|c|c|c|c|c|c|c|c|}
\hline \multicolumn{1}{|c|}{ ROE-r in \% } & $\mathbf{2 0 0 9}$ & $\mathbf{2 0 1 0}$ & $\mathbf{2 0 1 1}$ & $\mathbf{2 0 1 2}$ & $\mathbf{2 0 1 3}$ & $\mathbf{2 0 1 4}$ & $\mathbf{2 0 1 5}$ & $\mathbf{2 0 1 6}$ & $\mathbf{2 0 1 7}$ & $\mathbf{2 0 1 8}$ & Median \\
\hline ROE-r Hotel industry & $-15,04$ & $-18,01$ & $-19,05$ & $-27,64$ & $-17,42$ & $-22,49$ & $-10,20$ & $-5,96$ & $-5,38$ & $-4,94$ & $-16,23$ \\
\hline ROE-r Slovenian firms & $-7,80$ & $-9,80$ & $-8,38$ & $-9,53$ & $-9,92$ & $-7,42$ & $-4,66$ & $-1,42$ & $-0,35$ & 0,47 & $-7,61$ \\
\hline
\end{tabular}

Sources: Damodaran, 2019; FRED, 2019; European Central Bank, 2019; GVIN, 2019; Bloomberg, 2019; own calculations

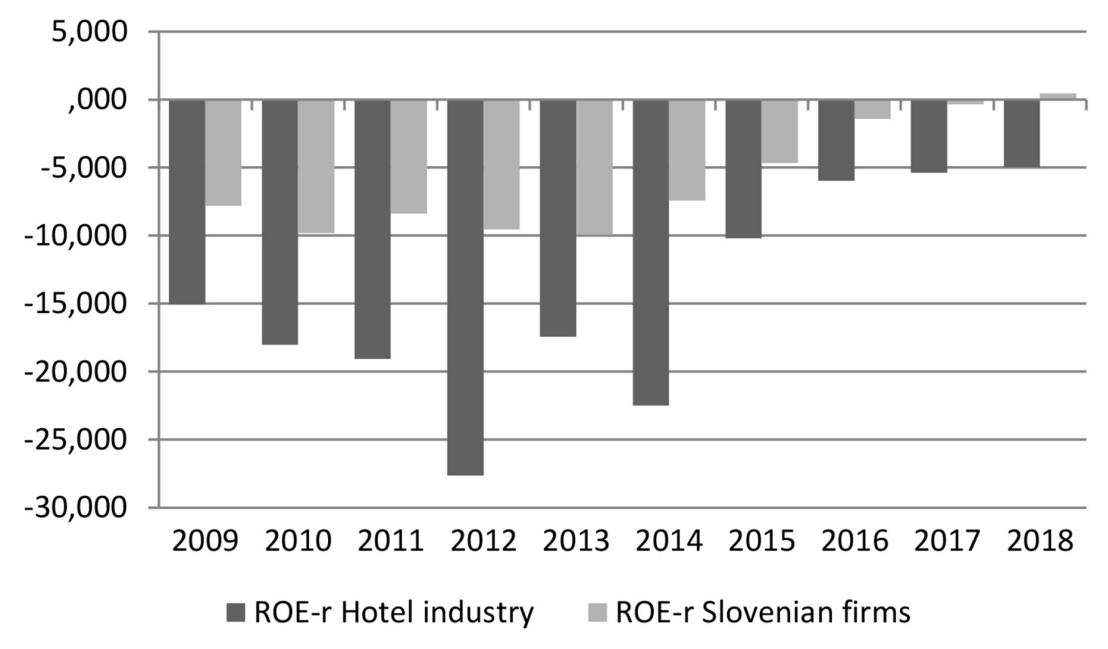

Figure 8. Relative residual income for Slovenian hotel industry firms and all Slovenian firms Sources: Damodaran, 2019; FRED, 2019; European Central Bank, 2019; GVIN, 2019; Bloomberg, 2019; own calculations

According to the Table 9 and Figure 8 we can argue (given the estimated required return on equity) that the Slovenian firms ROE is around "equilibrium" (required return on equity equals achieved return on equity) ${ }^{15}$ in years 2016-2018, but we cannot argue the same for the Slovenian hotel industry. However, also the relative residual income for all Slovenian firms is mostly negative in the observed period.

\section{CONCLUSION}

Due to the importance of the hotel industry for the Slovenian economy, we examined if the hotel industry had positive residual income and created value for its owners in the period 2009-2018. Stubelj et al. (2011) performed a similar analysis using data for the period 2005-2008, and the results showed that hotel industry was far from creating value for their owners. To bee sustainably profitable an industry must meet the needs of all stakeholders of which the most important are: owners, managers, employees, customers, suppliers, local community, and the state. Owners provide equity capital, which is a scarce commodity, and a firm essential resource. To raise enough equity capital for business needs and investment purposes the firm must be able to constantly achieve the capital firm purpose that is increase the value of assets to increase the value for owners.

$15 \quad$ With the limitation that theoretically we need some more net income for achieving the same market return (due to issuing costs of equity and transaction costs). This is also dependent of the market to book equity value ratio. We put equilibrium in parenthesis because we compare the required returns on equity with the achieved (ex-post) returns on equity and not the expected (ex-ante) returns on equity. 
We found that relative residual incomes of Slovenian hotel industry were not positive for the whole analyzed period 2009-2018, which means that firms did not create value for their owners and that they did not generate enough profits to cover the required return on equity capital, i.e. the required return on equity capital that takes into consideration the risk adjusted opportunity cost. The same resulted for groups of large, medium-sized, and small firms. The situation is improving but is still not at the desired level that is adding value of equity capital for owners. Our further analysis shows that the Slovenian hotel industry is riskier than all Slovenian firms (i.e. average risky firm) in the observed period. However, the return on equity is much lower than of all Slovenian firms in the observed period. This gives additional support to our findings.

There are many possibilities for further research. Future research could examine more in details the reasons that lead to negative residual income in the whole analyzed period. It would be also interesting to perform an international comparative analysis of performance. Such findings could be of a great support to hotel industry managers and policymakers.

\section{REFERENCES}

AJPES (2019). Financial data. Retrieved from: https://www.ajpes.si/fipo/

Arnold, G. (2013). Corporate financial management. Harlow: Pearson Education.

Balachandran, S., \& Mohanram, P. (2012). Using residual income to refine the relationship between earnings growth and stock returns. Review of Accounting Studies, 17(1), 134-165.

Biddle, G. C., Chen, P., \& Zhang, G. (2001). When Capital Follows Profitability: Non-Linear Residual Income Dynamics. Review of Accounting Studies, 6 (2), 229-65. https://doi. org/10.1023/A:1011666926073.

Blitz, D., Falkenstein, E., \& Van Vliet, P. (2014). Explanations for the volatility effect: An overview based on the CAPM assumptions. The Journal of Portfolio Management, 40(3), 6176.

Bloomberg. (2019). Financial data. Retrieved from https://www.bloomberg.com/europe

Brealey, R. A., Myers, S. C., Allen, F., \& Mohanty, P. (2012). Principles of corporate finance. New York: McGraw-Hill Education.

Brigham, E. F., \& Ehrhardt, M. C. (2011). Financial Management: Theory \& Practice. Mason, $\mathrm{OH}$ : Cengage Learning.

Brigham, E. F., \& Ehrhardt, M. C. (2017). Financial Management: Theory \& Practice. Mason, $\mathrm{OH}$ : Cengage Learning.

Cheng, Q. (2005). What determines residual income? The Accounting Review, 80(1), 85-112.

Christensen, P. O., Feltham, G. A., \& Wu, M. GH. (2002). Cost of capital in residual income for performance evaluation. The Accounting Review, 77(1), 1-23.

Damodaran, A. (2016). Damodaran on valuation: security analysis for investment and corporate finance. Hoboken: John Wiley \& Sons.

Damodaran. (2019). Damodaran online. Retrieved from http://pages.stern.nyu.edu/ adamodar/.

Dechow, P. M., Hutton, A. P., \& Sloan, R. G. (1999). An empirical assessment of the residual income valuation model. Journal of accounting and economics, 26(1-3), 1-34.

European Central Bank. (2009). Monetary policy. Retrieved from http://www.ecb.int/mopo/ html/index.en.html

European Parliament. Policy Department for Structural and Cohesion Policies. Directorate-General for Internal Policies. (2019). European tourism: recent developments and future challenges. Retrieved from http://www.europarl.europa.eu/RegData/etudes/ STUD/2019/629200/IPOL_STU(2019)629200_EN.pdf 
Fama, E. F., \& French, K. R. (1992). The Cross-Section of Expected Stock Returns. The Journal of Finance, 47(2), 427-65. https://doi.org/10.1111/j.1540-6261.1992.tb04398.x.

Feltham, G. A., \& Ohlson, J. A. (1996). Uncertainty resolution and the theory of depreciation measurement. Journal of accounting research, 34(2), 209-234.

Fernandez, P. (2015). CAPM: An Absurd Model. Business Valuation Review, 34(1), 4-23. doi. org/10.5791/0882-2875-34.1.4.

FRED. Federal Reserve Bank of St. Louis. Economic Data. Retrieved from http://www.ecb.int/ mopo/html/index.en.html

Glen, A. (2005). Handbook of Corporate Finance. Harlow, England: Prentice Hall.

GVIN. (2019). Financial data. Retrieved from https://www.bisnode.si/produkti/bisnode-gvin/

Halsey, R. F. (2001). Using the Residual-Income Stock Price Valuation Model to Teach and Learn Ratio Analysis. Issues in Accounting Education, 16(2): 257-272.

Jamin, G. (2005). Investment Performance of Residual Income valuation Models on the German Stock Market. Research Papers of the Institute for Business Management.

Kruschwitz, L., Löffler, A., \& Mandl, G. (2012). Damodaran's Country Risk Premium: A Serious Critique. Business Valuation Review, 31(2): 75-84.

Lintner, J. (1965a). Security Prices, Risk, and Maximal Gains From Diversification. The Journal of Finance, 20(4), 587-615.

Lintner, J. (1965b). The Valuation of Risk Assets and the Selection of Risky Investments in Stock Portfolios and Capital Budgets. The Review of Economics and Statistics, 47(1), 13-37.

Ljubljana Stock Exchange. 2017. Annual reports. Retrieved from http://www.ljse.si/cgi-bin/jve. cgi?doc $=676$

Lundholm, R., \& O'Keefe, T. (2001). Reconciling Value Estimates from the Discounted Cash Flow Model and the Residual Income Model. Contemporary Accounting Research, 18(2), 311-35. doi.org/10.1506/W13B-K4BT-455N-TTR2.

McGoun, E. G. (1993). The CAPM: a Nobel failure. Critical Perspectives on Accounting, 4(2), $155-177$.

Mossin, J. (1966). Equilibrium in a Capital Asset Market. Econometrica, 34(4), 768-783.

Ohlson, J. A. (1995). Earnings, book values, and dividends in equity valuation. Contemporary accounting research, 11(2), 661-687.

Ohlson, J. A. (2005). On Accounting-Based Valuation Formulae. Review of Accounting studies, $10,323-347$.

Sharpe, W. F. (1964). Capital Asset Prices: A Theory of Market Equilibrium under Conditions of Risk. The Journal of Finance, 19(3), 425-442.

STO. (2019). Tourism in numbers 2018. Retrieved from https://www.slovenia.info/sl/poslovne-strani/raziskave-in-analize/turizem-v-stevilkah

Stubelj, I., Jerman, M., \& Dolenc, P. (2011). Does the Hotel Industry Create Value for Owners? The Empirical Analysis of Residual Income: The Case of Slovenia and Croatia. Academica Turistica - Tourism and Innovation Journal, 4(1), 63-72.

Toms, S. (2012). Accounting based Risk Measurement: An Alternative to Capital Asset Pricing Model Derived Discount Factors. Australian Accounting Review, 22(4): 398-406. doi. org/10.1111/j.1835-2561.2012.00194.x.

Treynor, J. L. (1961). Market Value, Time, and Risk. Unpublished work.

Treynor, J. L. (1962). Toward a Theory of Market Value of Risky Assets. Unpublished work.

Vesenjak, P. (2018). Performance analysis of key financial ratios of hotels and similar establishments of Slovene tourism in the period 2007-2017 [Analiza ključnih kazalnikov poslovanja dejavnosti hotelov in podobnih nastanitvenih obratov v slovenskem turizmu v obdobju 2007-2017]. Days of Slovenian tourism 2018, Portorož, 9.10.2018. Retrieved from 
https://www.slovenia.info/sl/poslovne-strani/raziskave-in-analize/analiza-kljucnih-kazalnikov-poslovanja-dejavnosti-hotelov

World Travel \& Tourism Council. 2019b. Economic impact. Region data. Retrieved from https:// www.wttc.org/economic-impact/country-analysis/region-data

World Travel \& Tourism Council. Travel \& Tourism Economic Impact 2018 Europe. 2018. Retrieved from https://www.wttc.org/economic-impact/country-analysis/region-data

World Travel \& Tourism Council. Travel \& Tourism Economic Impact 2019 World. 2019a. https:// www.wttc.org/-/media/files/reports/economic-impact-research/regions-2019/world2019.pdf

Wright, S., Mason, R., \& Miles, D. (2003). A Study into Certain Aspects of the Cost of Capital for Regulated Utilities in the UK. Retrieved from http://regulationbodyofknowledge.org/wp-content/uploads/2013/03/Wright_-A_Study_into.pdf. 